\title{
A study of the economic and financial analysis for social firms: are they really businesses?
}

\author{
Vera Gelashvili $^{a}$, María del Mar Camacho-Miñano ${ }^{\mathrm{b}}$, María Jesús Segovia-Vargas $^{\mathrm{c}}$ \\ a) Departamento de Economía de la Empresa, Facultad de Ciencias Jurídicas y Sociales, Universidad Rey Juan Carlos. Madrid, España. \\ b) Departamento Administración Financiera y Contabilidad (AFCO), Fac. de Ciencias Económicas y Empresariales, Complutense de Madrid. Pozuelo de Alarcón. Madrid, \\ España. \\ c) Departamento de Economía Financiera y Actuarial y Estadística, Facultad Ciencias Económicas y Empresariales, Complutense de Madrid. Pozuelo de Alarcón. Madrid, \\ España.
}

${ }^{a}$ Corresponding author. E-mail address: vera.gelashvili@urjc.es

\section{A R T I C L E I N F O}

\section{Article history:}

Received 3 February 2019

Accepted 2 June 2019

Available online 1 July 2020

\section{JEL classification:}

J58

M4

M41

Keywords:

Social enterprises

Insertion firms

Insertion firms

Financial and economic analysis

\section{A B S T R A C T}

The main objective of this research paper is to analyze the economic and financial situation of social enterprises through ratio analysis and show their strengths and weaknesses based on financial data. The sample consists of 118 social companies operating in the Autonomous Community of Madrid in Spain. For data analysis, economic and financial analysis has been carried out, using ratio analysis and the indicator of financial distress: the Altman Z'-score. Our findings highlight that social companies are businesses with a high level of profitability, especially for their partners. Thus, their survival, on average, is guaranteed in the long-term and their liquidity level is optimum. This study is an important contribution for the academic literature, because it carries out a comparison amongst the two different types of social firms, focusing on their economic and financial structure, diminishing the lack of empirical studies about these companies.

(C)2020 ASEPUC. Published by EDITUM - Universidad de Murcia. This is an open access article under the CC BY-NC-ND license (http://creativecommons.org/licenses/by-nc-nd/4.0/).

Un estudio sobre el análisis económico-financiero de las empresas sociales: ¿son realmente negocios?

R E S U M EN

El principal objetivo de esta investigación es analizar la situación económico- financiera de las empresas sociales a través del análisis de ratios, mostrando sus fortalezas y debilidades basándonos en la información contable. La muestra está formada por 118 empresas sociales situadas en la Comunidad Autónoma de Madrid en España. Para analizar los datos se han utilizado ratios económico-financieros y el indicador de estrés financiero, el Z'-score de Altman . Nuestros resultados destacan que las empresas sociales son negocios con una elevada rentabilidad, especialmente para sus socios. De este modo, está garantizada su supervivencia en el largo plazo y con un nivel de liquidez óptimo. Este estudio es una importante contribución para la literatura académica porque establece una comparación entre dos tipos de negocios sociales centrándonos en su estructura financiera y económica, completando la escasez de estudios empíricos sobre estas empresas.

(C2020 ASEPUC. Publicado por EDITUM - Universidad de Murcia. Este es un artículo Open Access bajo la licencia CC BY-NC-ND (http://creativecommons.org/licenses/by-nc-nd/4.0/). 


\section{Introduction}

The first international studies on social enterprises and the new social economy were conducted in the mid-1990s (Quintão, 2007). Since then, researchers have shown a growing interest in businesses whose main objective is to serve a collective or the society in general, that is, the so-called 'social economy'. In a first approach, the social economy can be situated between the market economy and the public economy due to the fact that the members of social economy carry out business initiatives that incorporate economic affairs together with the social ones (Hernández, 1994). In the European Union, the social economy is playing an important role in creating employment, facilitating sustainable growth, matching services to needs and in distributing fairer income and wealth. For example, the European social economy provides over 13.6 million paid jobs equivalent to about $6.3 \%$ of the working population of the EU-28 (European Economic and Social Committee, 2016). The case of Spain is not a different one and the contribution of the social economy sector to the Spanish economy represents around 10\% of GDP and $12.5 \%$ of employment ${ }^{1}$. An integral part of the social economy are social enterprises (Monzón, 2013; Fajardo, 2014). These companies can be defined as initiatives that integrate a set of social and economic characteristics (Quintão, 2007), providing quality goods and services to the market (Jeffery, 2005). Social enterprises put social objectives above the economic ones, and if the enterprise is profitable, profits are often reinvested to promote the company's major social objectives (Del Negro, 2012). In Spain, social companies are constituted by social cooperatives, insertion companies, and sheltered employment centres (Díaz-Foncea \& Marcuello, 2012, Triper, 2015). Most of these studies are based on the importance of these companies or on their evolution in recent decades (Arthur et al., 2010; Díaz-Foncea et al., 2012; Cooney et al., 2016).

Consequently, the creation of social enterprises and the promotion of the figure of social entrepreneurship is a key question for the European Commission. As a result, the Social Business Initiative (SBI) was launched in 2011. The SBI aim is to create a favorable financial, administrative and legal environment for these enterprises so that they can operate on an equal footing with other types of enterprises in the same sector. This initiative tries to identify actions to make a real difference and improve the situation on the ground for social enterprises ${ }^{2}$

Despite the growing interest in social enterprises (Hernández \& Segovia-Vargas, 2016; Díaz-Foncea et al., 2012), there are still many gaps that have not been adequately examined as most studies are theoretical or based on the qualitative analysis (Simón et al., 2012). Researchers have highlighted the need for carrying out economic and financial studies about these firms and their survival (Haugh, 2007; Zahra et al., 2009).

The aim of this paper is to show the main features of social enterprises like the sheltered employment centres and insertion companies. From an economic and financial point of view, we are giving academic visibility to these type of businesses, due to their great contribution to the social corporate responsibility, and indirectly, to encourage the so-called social entrepreneurship. In addition, this study will contribute to the academic literature, showing strengths and weaknesses of social companies, based on financial data.

\footnotetext{
${ }^{1}$ According to CEPES report 2016 https://www.cepes.es/publicaciones

2 https://www.eesc.europa.eu/en/our-work/

opinions-information-reports/opinions/social-business-initiative
}

In order to achieve this objective, we have analysed $56 \%$ of the total number of sheltered employment centres and insertion companies which exist in the Autonomous Community of Madrid. An economic-financial analysis has been carried out through ratios of liquidity, solvency, and profitability divided into quartiles. After that, the indicator of financial distress, the Altman Z'-score, was calculated to classify the companies into three different groups: solvent, with solvency problems and with a high risk of bankruptcy.

The results obtained show that the social companies are profitable companies for their shareholders, but on average, their return on assets is low because their assets do not generate enough returns on their main activity. They have a high level of solvency in the long and short term and a high level of liquidity in the short term. The Z'-score confirms that almost $80 \%$ of analysed companies are solvent, since they are classified in the safe and grey zone. The main contribution of the paper is to reduce the gap existing in this area. In order to develop empirical research, that shows the main characteristics of social enterprises, we carried out an analysis of the economic and financial situation of these type of firms. We did this through a ratio analysis which showed their strengths and weaknesses, based on financial data.

The rest of the paper is organized as follows. A review of the existing literature on social enterprises is displayed in section 2 . The following section explains the empirical background. The results and discussion are presented in section 4. Finally, some conclusions are highlighted.

\section{Literature review}

\subsection{Concept and regulation of social business in Europe}

In 2011 the European Commission has defined the concept of the social firm in its communication Social Business Initiative. Creating a favorable climate for social enterprises, key stakeholders in the social economy and innovation, November

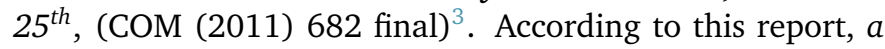
social enterprise is an operator in the social economy whose main objective is to have a social impact rather than make a profit for their owners or shareholders. It works by providing goods and services to the market in an entrepreneurial and innovative fashion and using its profits primarily to achieve social objectives. In addition, it is managed in an open and responsible manner and, in particular, involve employees, consumers, and stakeholders affected by its commercial activities.

Also, European communication identifies two types of social enterprises:

- businesses providing social services and/or goods and services to vulnerable persons (access to housing, healthcare, assistance for elderly or disabled persons, the inclusion of vulnerable groups, childcare, access to employment and training, dependency management, etc.); and/or

- businesses with a method of production of goods or services and also a social objective (social and professional integration via access to employment for people disadvantaged in particular by insufficient qualifications or social or professional problems leading to exclusion and marginalization), but whose activity may be outside the realm of the provision of social goods or services.

${ }^{3}$ http://eur-lex.europa.eu/legal-content/EN/TXT/?uri=COM:2011 0682:FIN 
As described before, the social economy gathers several entities but not all of them are social enterprises. Moreover, the European Commission declares that social enterprises combine societal goals with an entrepreneurial spirit. These organizations are focused on achieving wider social, environmental or community objectives. Therefore, there is a social dimension to its initiatives, that is, their main objective is to have a social impact rather than make a profit for their owners or shareholders. It operates by providing goods and services to the market in an entrepreneurial and innovative fashion and uses its profits primarily to achieve social objectives ${ }^{4}$.

\subsection{The Spanish context (regulators)}

The legal framework in Spain for social firms is the Law 5/2011, March $29^{\text {th }}$, on Social Economy. Recently, the entry into force of the Law $31 / 2015$, September $9^{\text {th }}$, has finished off this legal framework establishing measures of development and promotion of the Spanish social economy. This regulation defines 'social economy' as the private set of economic and business activities that pursue the interest of a particular collective or the general economic and social interest. The principles that guide this type of companies are based on the primacy of people over the capital, the social and equitable sharing of benefits and solidarity. Furthermore, the development, promotion, and encouragement of social entities are considered as a general interest task. Article 5 of Law $5 / 2011$ considers that social insertion enterprises, cooperatives, worker-owned companies, mutual companies, foundations and sheltered employment centres are part of the social economy.

The regulation of insertion enterprises in Spain is the Law 44/2007, December $13^{\text {th }}$. According to this law, it will be considered as an 'insertion enterprise' those firms, that legally constituted, duly qualified by relevant regional organizations in this field, perform any economic activity of producing goods and services, designed to make arrangements for social integration and social and labour training of people experiencing social exclusion as a transition to regular employment.

On the other hand, in Spain, sheltered employment centres are socially responsible companies because they play an important role in society helping people with disabilities to enter into the labor market but also in normal life. A sheltered employment centre is a business in which at least $70 \%$ of its workers are disabled people (with an official certification of disability degree higher than 33\%). Given that they are socially responsible companies, they receive public financial aid for their creation, for business payments, for social security, for maintenance of jobs, etc. (Royal Decree $1 / 2013$ of $29^{\text {th }}$ November).

Finally, the Law $27 / 1999$, July $16^{\text {th }}$, on cooperatives defines the social initiative cooperatives as those whose social objective is either the provision of assistance services to carry out health, educational, cultural or other activities of a social nature, or the development of any economic activity whose aim is the labour integration of people who suffer any kind of social exclusion and, in general, the satisfaction of social needs that are not met by the market.

It can be seen that in the different definitions of the three types of social enterprises there is a common factor, that is, to have a social impact. In other words, social enterprises operate by providing goods and services to the market in an entrepreneurial and innovative fashion and use their profits

${ }^{4}$ http://ec.europa.eu/growth/sectors/social-economy/enterprises/_es primarily to achieve social objectives ${ }^{5}$.

\subsection{Social firms in prior literature}

The main challenge that social enterprises have to face is to stay in the market in order to create social value. Therefore, social enterprises have to be a profitable business and, though there has been a hot debate about if this type of firms are for-profit or non-for-profit nature, we think that social value creation is compatible with being a profitable business (Drayton, 2002; Austin et al., 2006; Dorado, 2006; Van Slyke \& Newman, 2006; Arthur et al., 2010). The different aspects of social enterprises, like the economic and financial regulation of cooperative societies (Falcón \& Fuentes, 2017), the socio-economic impact of social enterprises at European level (Monzón, 2013), the analysis of the identity characteristics of the European social enterprise (Monzón \& Herrero, 2016) or the economic and financial analysis of the sheltered employment centres of different autonomous communities, (López et al., 2014; Gelashvili et al., 2015; Manzano et al., 2016) have been studied. López et al. (2014) analyze sheltered employment centres in Aragon and came to the conclusion that social activities are not sources of economic impact. A study carried out by Gelashvili et al. (2015) highlights the impact of public subsidies on the survival of sheltered employment centres in Spain. These results show that these companies, can be productive enterprises and survive in the market on average, without public subsidies, even though, their survival depends on their economic profitability and their turnover figure. Another economic and financial study about sheltered employment centres in Castilla y Leon (Manzano et al., 2016) has determined that public subsidies have increased in these companies in recent years, although depending on their legal form, they have been more or less affected by the economic crisis. However, there is little research about the economic and financial situation of social firms (Simón et al., 2012). Indeed, Haugh (2007) and Zahra et al. (2009) have pointed out the importance of studying the success and failure factors of social ventures.

Focusing on sheltered employment centres in Spain, the same as the rest of the firms, have to face the problem of their economic and financial viability. It is necessary to be competitive on the national or international level and to survive. This fact is especially important in the case of the sheltered employment centres because its origin is mainly linked to associations and foundations of family character. Consequently, in many cases, they lack the proper management and organization tools (Ferreras et al., 2011), what can lead them to fail.

The research carried out in Spain has studied their importance, legal and present situation during the last decades (Laloma, 2007; Cueto et al., 2008; Rodríguez et al., 2009; Jordán de Urríes \& Verdugo, 2010; Camacho-Miñano \& Pérez, 2012; Redondo \& Martín, 2014; Moratalla, 2016). All of them confirm that there is a growing trend in the creation of this particular type of business. Moreover, the number of employees and labor contracts have increased even during the economic crises (Rodríguez, 2012; Redondo, 2013). Nevertheless, there are just a few types of research about this type of firms from an economic and financial approach (Redondo y Martín, 2014; Gelashvili et al., 2015).

Regarding insertion enterprises, the situation is quite similar. According to Retolaza et al. (2014), the studies related to insertion firms can be grouped in three categories: the descriptive ones that tries to identify the main characteristics 
of these firms; the pedagogical ones that focus on their social utility, and finally, the management studies that tries to improve the management of the insertion firms. Precisely, in the management category, it can be observed the scarcity of research. Moreover, there are hardly any studies about their economic and financial situation (see, for example, Melián, et al., 2011; Retolaza et al., 2014).

Therefore, it is necessary to carry out studies that develop models and select the variables that could predict business failure (see Tascón \& Castaño, 2012). This is an interesting question because this kind of analyses would allow knowing the weaknesses of the firms and, consequently, to take the proper measures to survival.

As it was mentioned before, in Spain, social companies are composed of social cooperatives, insertion companies, and sheltered employment centres (Díaz-Foncea \& Marcuello, 2012). Literature revision has shown that there is a great scarcity of empirical analysis of these companies, which describes their economic and financial structure and shows their weak points and advantages. Therefore the main objective of this research paper is to analyze the economic and financial situation of social companies through ratio analysis and show their strengths and weaknesses based on financial data.

\section{Research design}

\subsection{Sample selection}

Due to the difficulties in accessing the list of social companies in Spain, the sample of this research is limited. Only Autonomous Community of Madrid (ACM) in our country publishes annually on line the updated list of different types of companies. The ACM is one of the autonomous communities where there is the greatest number of social enterprises (e.g. sheltered employment centres) with the highest number of employed persons and with different business activities (Gelashvili et al., 2015; Moratalla, 2016). Also, its position in indicators as per capita income, productivity, the level of employment, the attractiveness of investment or the effort in R\&D is relevant to be a leader region in Spain ${ }^{6}$. For this reason, our sample is made of sheltered employment centres and insertion companies. Even so, the list of social cooperatives was not available and we were unable to include these companies in the sample. Firstly, the information of the sample has been collected through the webpage of ACM. After that, the SABI ${ }^{7}$ database was used because it provides quantitative and qualitative information for Spanish businesses. For 2016, there were 14 insertion companies and 196 sheltered employment centres with financial data available. Due to lack of specific information we were not able to collect data of all these companies. As we can see in table 1, we were able to obtain the economic and financial information for $64 \%$ of the total number of insertion companies and $56 \%$ of the total of sheltered employment centres. Collected data represents $56 \%$ of the total sample not including social cooperatives.

Analysing the legal form of these social enterprises, there are 100 limited liability companies and 18 as a public limited company. This means that limited liability companies are suitable for activities in which the participation of few partners is foreseen, meanwhile public limited companies are

\footnotetext{
${ }^{6}$ http://www.caixabankresearch.com/documents/10180/65119/ CA-MAD-es.pdf

${ }^{7}$ https://sabi.bvdinfo.com
}

Table 1

Sample distribution

\begin{tabular}{lcccc}
\hline & $\begin{array}{c}\text { Insertion } \\
\text { companies }\end{array}$ & $\%$ & $\begin{array}{c}\text { Sheltered } \\
\text { employment centres }\end{array}$ & $\%$ \\
\hline Research sample & 9 & $64 \%$ & 109 & $56 \%$ \\
Total number & 14 & $100 \%$ & 196 & $100 \%$ \\
\hline
\end{tabular}

Source: own elaboration through SABI database and ACM web page

open companies, in which shareholders can freely sell their shares in the market. These 18 firms with public limited legal form belong to the sheltered employment centres.

Another important point of the sample is that most of them (36\%) are small companies (according to the number of employees), $31 \%$ of the sample belongs to medium enterprises and $21 \%$ to micro companies. Finally, the least represented in the sample are big companies with only $12 \%$ for the sample. The differences between micro, small and mediumsized enterprises, according to the European Union Commis$\operatorname{sion}^{8}$, take into account the number of employees. This way, companies with less than 10 employees are micro enterprises. Enterprises between 10 and 49 employees are defined as small enterprises. Companies between 50 to 249 employees are medium sized enterprises and, finally, large companies have more or equal than 250 employees.

Regarding the sector of activity (industry), 90 of these companies are active in the area of administrative, service and industry activities (including cleaning activities, food, textile, mining, manufacturing), 19 are engaged in trading activities wholesale and retail, repair of vehicles, transport, and storage. 11 of these companies provide information and communication services, professional, scientific and technical activities. Finally, 10 of the companies are active in health and social work activities. The others carry out different activities.

\subsection{Variables and research methodology}

An empirical study based on economic and financial analysis has been conducted in order to acquire first-hand knowledge of social firms, like sheltered employment centres and insertion companies in the Autonomous Community of Madrid (ACM). Specifically, we have used ratio analysis, because this method evaluates different aspects of the company, such as profitability, liquidity, and solvency. Table 2 shows all the ratios used in this research.

Table 2

Description of the variables

\begin{tabular}{ll}
\hline $\begin{array}{l}\text { Profitability ratios } \\
\text { Return on assets (ROA) } \\
\text { Return on equity (ROE) }\end{array}$ & (Operating result / Total assets) *100 \\
$\begin{array}{l}\text { Profit margin on sales } \\
\text { Liquidity ratios }\end{array}$ & (Net income / Net sale) *100 \\
$\begin{array}{l}\text { Current ratio } \\
\text { Quick ratio }\end{array}$ & Current assets / Current liabilities \\
Cash ratio & (Current assets - Inventory) / Current liabilities \\
Solvency ratios & Cash and cash equivalent / Current liabilities \\
$\begin{array}{l}\text { Debt to total assets ratio Total liabilities /Total assets } \\
\text { Equity ratio }\end{array}$ & $\begin{array}{l}\text { Equity / Total assets } \\
\text { Basic funding ratio }\end{array}$ \\
\hline
\end{tabular}

Source: own elaboration

The most important ratios to analyze the economic and financial situation of companies are shown in table 2. These

\footnotetext{
${ }^{8}$ http://ec.europa.eu/growth/smes/business-friendly-environment/ sme-definition/_en
} 
ratios are clustered in three groups. Group one belongs to profitability ratios. These ratios have been used in different studies to determine a firm's profitability (José et al., 1996; Suarez, 2000; Retolaza et al., 2014). Group two of ratios belongs to liquidity ratios, which measure the ability of a company to meet their short-term liabilities. In other words, it shows if the company is able to settle its short-term liabilities to turn current assets into cash. This group of ratios is often used to predict the failure of the companies (Dimitras et al., 1996). Solvency ratios represent the third group of ratios of this analysis. By means of these ratios, it could be analyzed the company's ability to pay their total debt. Solvency ratios are widely used to predict the survival of the company in the long-term period (Carmona et al., 2013). Additionally, variables as age and size of the company (measured as a number of the employees) were included in the analysis. Altman (1968) has shown in his study that younger companies are more likely to go to bankruptcy than companies with experience. This statement has also been proved in different studies about the survival of the companies and the results provide evidence that firms with experience in the market are less likely to fail (Evans, 1987; Moreno et al., 2003; Segarra \& Teruel, 2007). Another factor to explain the survival of the companies is the size. Research on this matter points out that companies with greater size are less likely to fail and have more probability to be profitable (Evans, 1987; González, 1997; De Andrés, 2000; Situm, 2014).

Finally, after obtaining economic and financial information of social firms through ratio analysis, these companies have been classified as healthy, doubtful and insolvent, following the Altman Z'-score (1968). The Z-score provides a probability of bankruptcy or firms' failure (for more detail of this indicator, see Altman et al., 2017). The Z-score formula has been calculated to contrast the result of ratios about the survival of social firms.

\section{Results and discussion}

\subsection{Ratio analysis}

Table 3 shows descriptive analysis of all variables used in this study. The first interesting result is that most of these companies have experience in the market since the average number of years is 17. The oldest social enterprise in Madrid has 61 years and the most recently founded firmt's age is 6 . Regarding the size, the number of employees varies from 1 to 7,905 employees, which means that the social enterprises in ACM include SMEs, as well as large companies. The descriptive analysis of their ratios shows that there are some companies with a high level of negative profitability based on their main activity and sales. Nevertheless, there are other companies with high positive profitability, reaching a return on assets of $123.07 \%$ or a return on equity of $209.36 \%$. This latter case indicates that there are companies that generate a very high profit for their shareholders. Liquidity analysis of social companies in the short term shows that for some companies it is a problem to cover their current liabilities and for some of them the level of cash and cash equivalents is equal to zero. On the other hand, there are companies with an excessive level of cash, having them five times higher than current liabilities. Regarding solvency ratios, we can observe that there are companies with a high level of solvency, meanwhile, other social companies are almost bankrupt. These results indicate that social enterprises are different from each other, so there is a lot of difference between their profitability, solvency, and liquidity.
Table 3

Descriptive Statistics

\begin{tabular}{lcccc}
\hline \multicolumn{5}{c}{ Descriptive Statistics } \\
\hline & Minimum & Maximum & Mean & $\begin{array}{c}\text { Std. } \\
\text { Deviation }\end{array}$ \\
Age (years from the foundation) & 6 & 61 & 17.13 & 7.70 \\
Size (number of employees) & 1 & 7905 & 208 & 794.28 \\
ROA \% & -166.10 & 123.07 & 3.55 & 25.85 \\
ROE \% & -329.69 & 209.36 & 7.48 & 48.26 \\
Profit margin on sales \% & -109.24 & 45.38 & 0.83 & 21.58 \\
Current ratio & 0.22 & 13.59 & 2.46 & 2.29 \\
Quick ratio & 0.21 & 12.53 & 2.35 & 2.28 \\
Cash ratio & 0.00 & 5.04 & 0.48 & 0.79 \\
Debt to total assets ratio & 0.04 & 2.92 & 0.58 & 0.41 \\
Equity ratio & -1.92 & 0.96 & 0.42 & 0.41 \\
Basic funding ratio & -10.17 & 24.33 & 3.40 & 5.08 \\
\hline
\end{tabular}

Source: own elaboration

We will analyze an average of each ratio separately clustering for three groups as it is shown in table 2 . In view of results of the key ratios for the companyt's economic and financial analysis, the correlation matrix has been made between variables analyzed. Results have shown that there is a positive correlation between age and size of the social companies. ${ }^{9}$ This means that social companies number of employees (measured as size) increases proportionally over the years.

\section{Profitability ratios}

The results of the descriptives summarize the main ratios that measure the profitability of social firms. The average of ROA is equal to $3.55 \%$, this means that for every 100 euros invested in assets, 3.55 of operating profit is generated. In other words, they generate 3.55 euros for the performance of their main activity. Comparing the result of ROA of the social firms with the profitability of shareholders (ROE), the outcomes of ROE are twice as big as the average of ROA. Results have shown that owners of this company for 100 invested received back 7.48 .

The ratio of profit margin on sales (also called return on sales ratio) is the last ratio in this group to analyze. The profit margin on sales shows what percentage of sales is left over after all expenses are paid by the business. In the case of social firms, this ratio has a positive value 0.83 and it indicates that this kind of companies, on average, has a low net result.

To deepen in the situation of these companies, we have used descriptive analysis by quartiles.

Table 4

Descriptives of the profitability ratios by quartiles

\begin{tabular}{lllll}
\hline & $\mathrm{N}^{\circ}$ & Q1 & Q2 & Q3 \\
\hline ROA \% & 118 & 0.52 & 3.66 & 9.75 \\
ROE \% & 118 & 0.99 & 6.4 & 22.71 \\
Profit margin on sales\% & 118 & 0.40 & 2.3 & 8.61 \\
\hline
\end{tabular}

Source: own elaboration

If we analyze the ROA by quartiles (table 4), there is a big difference between Q1 and Q3. Even if the sample is not very large, there are companies that have economic profitability less than $1 \%$ and others reach almost $10 \%$ of ROA. The same is true if we analyse the financial profitability of these 118 companies. Analyzing shareholders profitability, there is a group of companies (Q3) that has a very high return for their owners. In the case of the ratio profit margin on sales, the results of quartiles have shown that the median of the profits from sales after paying all expenses is equal to $2.3 \%$.

\footnotetext{
${ }^{9} 0.571^{* * *}$ ( ${ }^{* *}$ Correlation is significant at the 0.01 level (2-tailed)).
} 
In general, analysed companies are quite different according to their profitability, but they do not present negative results. These results lead us that, generally, social companies are profitable companies according to their main activity.

\section{Liquidity ratios}

The outcomes of the descriptives summarize the liquidity of social firms. Current ratio result presents that social companies have enough ability to pay off its short-term liabilities with its current assets since their average is 2.46 . This means that the current assets of these companies are more than twice greater than their current liabilities. In the case of the quick ratio, the result is also greater than 2 that means that these companies are able to pay their current liabilities without selling inventory in 90 days. Regarding the cash ratio, the result is 0.48 . As the opportunity cost could be high, these companies, on average, have enough cash as they need.

Overall the result of the liquidity ratios has shown that social firms are attractive to their creditors because their economic and financial situation enables them to have enough liquidity in short-term. For further analysis, the sample has been divided into quartiles (table 5).

Table 5

Descriptives of the profitability ratios by quartiles

\begin{tabular}{lllll}
\hline & N $^{\circ}$ & Q1 & Q2 & Q3 \\
\hline Current Ratio & 118 & 1.17 & 1.61 & 2.85 \\
Quick Ratio & 118 & 1.05 & 1.55 & 2.59 \\
Cash Ratio & 118 & 0.05 & 0.16 & 0.55 \\
\hline
\end{tabular}

Source: own elaboration

\section{Solvency ratios}

Descriptive statistics include the results of the solvency ratios, especially for long-term. In general, the data show that social companies are solvent companies, and the basic funding ratio has 4.12, higher value in this group. This result indicates that these companies, on average, have an excess of financing. If the basic funding ratio is around one, it means that the economic and financial structure of the companies is very balanced (Nieto, 2004). If the basic funding ratio is greater than one, it means that part of the current assets is being financed by non-current liabilities, which at first sight means a good degree of solvency. Although a high level of this ratio could indicate that these companies have an excess of long term liabilities, capital grants or positive result of the permanent capital structure. If this excess had been caused by long-term external financing, this would have increased financial expenses for these companies in the future. In any case for an analized period, this result indicates that these companies are solvent companies according to the result.

Analyzing debt to total assets ratio (also known as the guarantee ratio), which measures the overall solvency of the companies in the long term, there is a high standard deviation, but the result guarantee creditors interest in this type of companies. Equity ratios that belong to solvency ratios or investment leverage, measures the amount of the assets financed by shareholders equity. The result shows that on average internal resources (shareholders equity) finance $42 \%$ of the assets available in these companies. Although if we analyze the equity ratio by quartiles (table 6), we see that companies that are grouped in Q3 finance 67\% of total assets through shareholdert's equity. Meanwhile, other companies from Q1 finance only $25 \%$ of their assets through equity.

Analyzing debt to total assets ratio by quartiles, the companies that are in Q1 have 33\% of their total assets financed by total liabilities, meanwhile, the median of this ratio stands
Table 6

Descriptives of the solvency ratios by quartiles

\begin{tabular}{lllll}
\hline & $\mathrm{N}^{\circ}$ & $\mathrm{Q} 1$ & $\mathrm{Q} 2$ & $\mathrm{Q} 3$ \\
\hline Debt to total assets ratio & 118 & 0.33 & 0.52 & 0.75 \\
Equity ratio & 118 & 0.25 & 0.48 & 0.67 \\
Basic funding ratio & 118 & 1.06 & 1.59 & 3.74 \\
\hline
\end{tabular}

Source: own elaboration

at $52 \%$, the companies that are grouped in Q3 indicate that $75 \%$ of their assets are financed through debts. The results of the last ratio analyzed in this group have shown that all quartile results are at an optimal level.

\subsection{Z-score analysis}

The Altman Z-score (1968) has been selected to measure the financial health of social companies. Based on Altman's experience with companies in financial difficulties, an index was developed using five ratios and five weights to forecast the bankruptcy of listed manufacturing companies. This model has been adjusted over time and the Z' score was adapted for companies that were not listed on secondary markets. As our sample is for non-listed companies, the model has the following formulation:

$$
Z^{\prime}=0.717 X_{1}+0.847 X_{2}+3.107 X_{3}+0.420 X_{4}+0.998 X_{5}
$$

Where $\mathrm{Z}^{\prime}$ is the index of bankruptcy; $\mathrm{X} 1=$ (Current Assets-Current Liabilities)/Total Assets; X2= Retained Earnings/Total Assets; X3= Earnings before Interest and Taxes/Total Assets; X4= Book Value of Equity/Total Liabilities; X5 = Sales/Total Assets. Results of Z's score show that, in practice, companies can be classified into three different areas:

Z' > 2.9 -"Safe" zone; it means that the company has no risk of bankruptcy.

$1.23<$ Z' $<2.9$ - "Grey" zone; it means that company could have problems to survive in the next period.

Z' $<1.23$-"Distress" zone; it means that there is a high probability that the company will go bankrupt.

According to the Z-score formula, the sample of this research has been classified by these three groups (Safe; Grey; Distress). The results are shown in table 7.

Table 7

Z-score table

\begin{tabular}{llll}
\hline & Safe zone & Grey zone & Distress zone \\
\hline N $^{\circ}$ & 42 & 51 & 25 \\
$\%$ & $36 \%$ & $43 \%$ & $21 \%$ \\
\hline
\end{tabular}

Source: own elaboration

The result shows that from 118 analyzed companies, 42 of them belong to the safe zone, which is $36 \%$ of the final sample. This means that these companies would be far away from bankruptcy. In the grey zone, there are $43 \%$ of social companies. This result implies that 51 companies from the sample probably will have problems of survive in the future, but this does not mean that they are going bankrupt. So these companies should take steps to avoid insolvency in the next period. The last group from table 7 is distress zone, where are summarized 25 companies according to the formula. Distress zone shows the companies with a high probability of bankruptcy. These mean that $21 \%$ of the analyzed social companies have a probability of failure. 
Taking all this in mind we can say that, generally, social companies are solvent companies, since most of them (79\%) are classified in the safe and grey zones. This outcome is reinforced by the results of the ratios analysis, where has been shown that, on average, the companies analysed are solvent companies and do not have liquidity problems, especially in the short term.

\section{Conclusions}

The main objective of this study is the economic and financial analysis of the social firms in a region of Spain. Firstly, we have observed that there are very few previous studies on the economic-financial viability of this type of companies. Secondly, as we have seen by carrying out this study, there are difficulties in accessing the data of these companies. Although the ACM is the only community that publishes the list of different companies, there was not available the list of social cooperatives. This lack of transparency of information leads to a lack of visibility of this social reality and, at the same time, makes difficult to carry out a general analysis of this type of companies.

Analyzing the different variables like age and size of these companies, the results show that they are companies with experience in the market because, among the analyzed companies, the firm with the least experience in the market was 6 years of age for 2016. Regarding the size of companies, we have seen that the average number of employees for social companies in ACM is 208, this indicates that they are companies that usually invest their profits in the growth of the company.

The economic and financial analysis of social companies through ratio analysis has shown that they are normally companies with a high level of solvency. In fact, the three ratios that analyzed in this group has shown the high average of solvency in short and long-term. This result indicates that these companies are able to meet their debt. Profitability ratios analysis shows that social companies' average of return on assets is low because their assets do not generate sufficient return on their main activity, although they are profitable for their shareholders. The result of liquidity ratios has disclosed that social firms on average are companies with a high level of liquidity and enable them to have enough liquidity in shortterm.

Moreover, most of the social companies of our sample are out of bankruptcy situations. The result of the Z-score has shown that almost $80 \%$ of social companies are solvent companies since they are classified in the safe and gray zone.

Even though the results only belong to one region in Spain, this study is an important contribution to prior literature, giving academic visibility to social enterprises as solvent companies with a low probability of bankruptcy, filling the gap that exists in the economic and financial analysis of these companies. Also, this study will serve to promote social entrepreneurship, since the empirical results show that they are companies that do not have a problem of survival in the market. Finally, we want to give social visibility to these type of companies, which create a better world every day for everyone.

This study has some main implications: the first one is for governments because they must provide access to public data. Otherwise it is not possible to do generalized research, where the results would be of great utility for the companies as well as for the academic literature. And the second implication, is for entrepreneurs, who must take into account this type of companies, as they normally generate a profit for their shareholders and create social value.

However, this study is not free from limitations. The sample is focused on only one region of Spain and it has not been possible to obtain data for social cooperatives, which makes it impossible to analyze or make a comparison between the three types of social enterprises in Spain.

Future studies should be done using the whole number of social firms, analysing their economic and financial viability and showing which variables are important for their profitability and survival. Additionally, a comparison of the three types of social enterprises, will be made in order to make their economic and financial results clearer. Perhaps there are some factors that could condition the profitability or solvency of social cooperatives, but not of sheltered employment centres or insertion companies (or vice versa). Future research should be carried out in this area.

Finally, social companies have great importance because, they are businesses that are part of the social economy of the country and contribute to the improvement of society or environment for everyone. Taking into account the lack of information about these companies, the purpose of this study will serve to give academic and social visibility to these firms, based on the economic and financial analysis. This, in turn, could encourage or foster the creation of these type of companies.

\section{Acknowledgment}

The first version of this research paper was presented at the international congress of ASEPUC-2018 and was awarded as the best communication in English. We would like to express our sincere gratitude to the organizers of this Conference, to our discussant Dr. Ana Licerán Gutiérrez, to anonymous reviewers of RC-SAR journal and our handling editor of the RC-SAR journal for their truly valuable comments.

\section{Conflict of interests}

The authors declare no conflict of interest.

\section{References}

Altman, E.I. (1968). Financial ratios, discriminant analysis and the prediction of corporate bankruptcy. The Journal of Finance, 23, 589-609. https://doi.org/10.2307/2978933

Altman, E.I., Iwanicz-Drozdowska, M., Laitinen, E.K. and Suvas, A. (2017). Financial Distress Prediction in an International Context: A Review and Empirical Analysis of Altman's ZScore Model. Journal of International Financial Management \& Accounting, 28(2), 131-171. https://doi.org/10. $1111 /$ jifm.12053

Arthur, S., Keenoy, T., Scott-Cato, M., \& Smith, R. (2010). Where is the social in social enterprise?, in Fuller D, Jonas AEG, Lee R (eds) Alternative spaces of economy, society and politics: interrogating alterity. Ashgate, Aldershot, 207-222.

Austin, J., Stevenson H., \& Wei-Skillern J. (2006).* Social and commercial entrepreneurship: same, different, or both?. Entrepreneurship Theory and Practice 30(1), 1-22. https:// doi.org/10.1111/j.1540-6520.2006.00107.x

Camacho-Miñano, M. M., \& Pérez. R. (2012). Centros Especiales de Empleo: Empresas para una sociedad com- 
prometida responsablemente. Responsabilidad Social Empresarial, 12, 77-89.

Carmona, P., Martínez, J., \& Pozuelo, J. (2013). Diagnóstico económico-financiero de la empresa cooperativa. Un estudio comparado de los años 2004 y 2007. REVESCO. Revista de Estudios Cooperativos, 110, 43-95. http://dx.doi. org/10.5209/rev/ REVE.2013.v110.41444

Cooney, K., Nyssens, M., O’Shaughnessy, M., \& Defourny, J. (2016). Public Policies and Work Integration Social Enterprises: The Challenge of Institutionalization in a Neoliberal Era. Nonprofit Policy Forum, 7(4), 415-433. https: //doi.org/10.1515/npf-2016-0028

Cueto, B., Malo, M.A., Rodríguez, V., \& Franco, C. (2008). Trayectorias laborales de las personas con discapacidad y centros especiales de empleo: Análisis empírico con la Muestra Continua de Vidas Laborales. Fipros Seguridad Social. Available through URL: http://www.seg-social.es/ prdi00/groups/public/documents/binario/119779.pdf

De Andrés, J. (2000). Caracterización económicofinanciera de las empresas asturianas en función de su nivel de rentabilidad. RAE: Revista Asturiana de Economía, 18, 191222.

Del Negro, G. (2012). Las empresas sociales de inserción frente a la exclusión social. Revista Prisma Social, 9, 285-310.

Díaz-Foncea, M., \& Marcuello, C. (2012). Las empresas sociales en España: concepto y características. GEZKIUPV/EHU Revista Vasca de Economía Social, 8, 143-164.

Díaz-Foncea, M., Marcuello, C., \& Marcuello, C. (2012). Empresas sociales y evaluación del impacto social. CIRIECEspaña, Revista de Economía Pública, Social y Cooperativa, 75, 179-198.

Dimitras, A.I., Zanakis, S., \& Zopounidis, C. (1996). A survey of business failures with an emphasis on prediction methods and industrial applications. European Journal of Operational Research, 90(6), 487-513. https://doi.org/10.1016/ 0377-2217(95)00070-4

Dorado, S. (2006). Social entrepreneurial ventures: different values so different process, no? Journal of Developmental Entrepreneurship 11(4), 319-343. https://doi.org/10.1142/ S1084946706000453

Drayton, W. (2002). The citizen sector: becoming as entrepreneurial and competitive as business. California Management Review 44(3), 120-133. https://doi.org/10.2307/ 41166136

European Economic and Social Committee. (2016). Recent evolutions of the Social Economy in the European Union. Available on: http://www.eesc.europa.eu/sites/ default/files/files/qe-04-17-875-en-n.pdf

Evans, D. S. (1987). The relationship between firm growth, size, and age: Estimates for 100 manufacturing industries. The Journal of Industrial Economics, 4(35), 567-581. https://doi.org/10.2307/2098588

Ferreras, A., Suárea, E.S., Oltra, A., Ruiz, R., Pizarro, C., \& García, N. (2011). Los Centros Especiales de Empleo en la Comunidad Valenciana: problemática y propuestas de mejora. Valencia: Instituto de Biomecánica de Valencia.

Fajardo, G. G. (2014). El concepto legal de economía social y la empresa social. Gizarte Ekonomiaren Euskal Aldizkaria-Revista Vasca de Economía Social, 8, 63-84.

Falcón, C. F. P., \& Fuentes, J. F. P. (2017). Un modelo económico-financiero alternativo: las organizaciones de la economía social. Lex Social: Revista de Derechos Sociales, 7(2), 229-249.

Gelashvili, V., Camacho-Miñano, M. M., \& Segovia, M. J. (2015). Patrones de supervivencia para la gestión de los centros especiales de empleo. Revista de Estudios Empresariales. Segunda Época, 1, 109-126.

González, A. (1997). La rentabilidad empresarial: evaluación empírica de sus factores determinantes. Colegio de Registradores de la Propiedad y Mercantiles de España; Centro de Estudios Registrales.

Haugh, H. (2007). Community-led social venture creation. Entrepreneurship Theory and Practice, 31(2), 161-182. https: //doi.org/10.1111/j.1540-6520.2007.00168.x

Hernández, F. (1994). Estructura y Resultados de la Economía Social en Castilla-La Mancha. Rasgos Diferenciadores. Tesis Doctoral: Servicio de Publicaciones de la Universidad de Castilla La Mancha.

Hernández, M. T. B., \& Segovia-Vargas, M. J. (2016). Economía social y empresas sociales: Caritas Española como emprendedora social. Sociedad y utopía: Revista de Ciencias Sociales, 47, 102-125.

Jeffery, S. (2005). Social firms: Developing business, economic viability, stakeholder value and worker inclusion. In International Congress series, Elsevier, 1282, 1153-1157.

Jordán De Urríes, F.B., \& Verdugo, M.A. (2010). Informe sobre la situación de los Centros Especiales de Empleo en España. Salamanca, Spain. INICO.

José, M. L., Lancaster, C., \& Stevens, J. L. (1996). Corporate returns and cash conversion cycles. Journal of Economics and Finance, 20(1), 33-46. https://doi.org/10.1007/ BF02920497

Laloma, M. (2007). Empleo protegido en España: Análisis de la normativa legal y logros alcanzados. Madrid, Spain. Ediciones Cinca S.A.

López, F. J. A., Mateos, M. L., Olmo, J. V., Suárez, I. P., Bellostas, A. J. P., \& Brusca, M. I. A. (2014). Actividades e impactos de la empresa social. Estudio de los Centros Especiales de Empleo aragoneses. CIRIEC-España, Revista de Economía Pública, Social y Cooperativa, 81, 217-239.

Manzano, M.M.I., Redondo, M.M.N., \& Robles, M.P.P. (2016). Los centros especiales de empleo en Castilla y León, 2007-2013: efectos de la crisis en función de la personalidad jurídica que adoptan. REVESCO: Revista de Estudios Cooperativos, 122, 191-218.

Melián, A., Campos, V., \& Sanchis, J. R. (2011). Emprendimiento social y empresas de inserción en España. Aplicación del método Delphi para la determinación del perfil del emprendedor y las empresas sociales creadas por emprendedores. REVESCO: Revista de Estudios Cooperativos, 106, 150-172. https://doi.org/10.5209/rev/ REVE.2011. v106.37377

Monzón, J. L. C. (2013). Empresas sociales y economía social: perímetro y propuestas metodológicas para la medición de su impacto socioeconómico en la UE. Revista de Economía Mundial, 35, 151-163.

Monzón, J. L. C., \& Herrero, M. M. (2016). Identificación y análisis de las características identitarias de la empresa social europea: aplicación a la realidad de los Centros Especiales de Empleo de la economía española. CIRIEC-Espana, 87, 295326.

Moratalla, P. S. (2016). Centros especiales de empleo. Revista Jurídica de Economía Social y Cooperativa, 29, 1-39.

Moreno, J., García Tabuenca, A., \& Pablo Martí, F. (2003). Análisis de la relación entre el crecimiento empresarial, la edad de la empresa y la estructura de propiedad. Available on: https://ebuah.uah.es/dspace/bitstream/handle/ 10017/6491/analisis/ moreno/ SERVILABDT/ 2003.pdf? sequence $=1$ \&isAllowe $\overline{\mathrm{d}}=\mathrm{y}$

Nieto, A. (2004). Administración de empresas, volumen I. 
Sevilla, Spain. Editorial MAD.

Quintão, C. (2007). Empresas de inserción y empresas sociales en Europa. CIRIEC-España, Revista de Economía Pública, Social y Cooperativa, 59, 33-59.

Redondo, M.N. (2013). Comportamiento económicofinanciero de los Centros Especiales de Empleo en Castilla y León. Años 2004-2010. Tesis doctoral. Departamento de Economía Financiera y Contabilidad. Universidad de Valladolid.

Redondo, M. N., \& Martín, I. (2014). Supervivencia de los Centros Especiales de Empleo en la Comunidad Autónoma de Castilla y León. AECA: Revista de la Asociación Española de Contabilidad y Administración de Empresas, 108, 25-28.

Retolaza, J. L, San José, L., \& Araujo, A. (2014). La eficiencia como reto de las empresas de inserción. REVESCO, Revista de Estudios Cooperativos, 115, 159-185.

Rodríguez, G., García, C., \& Toharia, L. (2009). Evaluación de las políticas de empleo para personas con discapacidad y formulación y coste económico de nuevas propuestas de integración laboral. Madrid, Spain. Ediciones CINCA, S.A.

Rodríguez, V. (2012). El empleo de las personas con discapacidad en la gran recesión: £Son los Centros Especiales de Empleo una excepción?. Estudios de Economía Aplicada, 1(30), 10-24.

Royal Decree $1 / 2013$, of 29th November, approving the Consolidated Text of the General Law on the Rights of People with Disabilities and their Social Inclusion

Segarra, A., \& Teruel, M. (2007). Creación y supervivencia de las nuevas empresas en las manufacturas y los servicios. Economía Industrial, 363, 47-58

Simón, M. V., Revuelto, T. L., \& Ribeiro, S. D. (2012). Are Success and Survival Factors the Same for Social and Business Ventures?, Service Business, 6 (2), 219-242. https: //doi.org/10.1007/s11628-012-0133-2

Situm, M. (2014). The age and the size of the firm as relevant predictors for bankruptcy. Journal of Applied Economics and Business, 2(1), 5-30

Suarez, J. (2000). Caracterización económico-financiera de las empresas asturianas en función de su nivel de rentabilidad. RAE: Revista Asturiana de Economía, (18), 191-222.

Tascón, M., \& Castaño, F. (2012). Variables y modelos para la identificación y predicción del fracaso empresarial: revisión de la investigación empírica reciente. Revista de Contabilidad - Spanish Accounting Review, 15(1), 7-58. https: //doi.org/10.1016/S1138-4891(12)70037-7

Triper, B. (2015). El Emprendimiento Social como parte de la Economía Social. Madrid, España: Servimedia. Available at: http://www.cepes.es/publicaciones

Van Slyke, D.M., \& Newman, H.K. (2006). Venture philanthropy and social entrepreneurship in community redevelopment. Nonprot Management Leadership 16(3), 345-368. https://doi.org/10.1002/nml.111

Zahra, S.A., Gedajlovic, E., Neubaum, D.O., \& Shulman, J.M. (2009). A typology of social entrepreneurs: motives, search processes and ethical challenges. Journal of Business Venturing, 24(5), 519-532. https://doi.org/10.1016/j. jbusvent.2008.04.007 